Pandecta

\title{
Afirmasi Kebijakan Pemerintah dalam Fasilitasi Kerja bagi Penyandang Disabilitas
}

\author{
Zulfah Latuconsina ${ }^{\bowtie}$
}

Assistant Legal Specialist, PT.Huawei Tech Invesment, Indonesia

\section{Info Artikel}

Sejarah Artikel:

Diterima Oktober 2014

Disetujui November 2014

Dipublikasikan Desember 2014

Keywords:

The affirmative policies

goverment;

The Right of Work;

The Disabilities

\begin{abstract}
Abstrak
Penelitian ini bertujuan untuk mengetahui bentuk afirmatif kebijakan pemerintah dalam fasilitasi kerja bagi penyandang disabilitas di Provinsi Jawa Tengah, persepsi penyandang disabilitas terhadap afirmatif kebijakan pemerintah, dan mengetahui kendala yang dihadapi dalam pelaksanaan afirmatif kebijakan pemerintah tersebut. Jenis penelitian ini adalah yuridis sosiologis dengan menggunakan pendekatan deskriptif. Hasil penelitian menunjukan bahwa kuota minimal hak kerja bagi penyandang disabilitas tidak terpenuhi. Namun pemerintah masih berupaya untuk mewujudkan hal tersebut. Upaya ini diwujudkan melalui afirmatif kebijakan pemerintah dalam fasilitasi kerja bagi penyandang disabilitas, yaitu dengan memberikan pelatihan keterampilan, bantuan sosial bagi penyandang disabilitas dan pembentukan Peraturan Daerah Provinsi Jawa Tengah Tentang Pemenuhan Hak Penyandang Disabilitas yang sejauh ini masih dalam tahap Rancangan Peraturan Daerah (Raperda). Persatuan Penyandang Cacat Indonesia menilai bahwa pelatihan yang diberikan pemerintah dirasa sudah tidak sesuai lagi dengan perkembangan jaman dan kebutuhan hidup penyandang disabilitas. Hal serupa turut disuarakan oleh Gerkatin. Sedangkan tentang kehadiran Raperda, baik Persatuan Penyandang Cacat Indonesia maupun Gerkatin memberikan respon positif. Adapun faktor penyebab afirmatif kebijakan pemerintah yang berlaku saat ini belum dapat berjalan dengan baik dikarenakan ketidakpatuhan pihak - pihak serta ketidaktahuan pihak perusahaan mengenai adanya aturan tentang kuota minimal hak kerja bagi penyandang disabilitas.
\end{abstract}

\begin{abstract}
The purposes of this study are to knows the form of affirmative policies of local goverment to facilitating of work to disabilities, to knows how the respons of disabilities, and to knows what the obstacles to implementation those policies. This study is using sosio - juridical with descriptive approach. The result of this study is showing that the minimum quota of disabilities's work right is insatiable. But the local goverment's keeping try to actualizing it with their affirmative policies. These affirmative policies exist to faciliting disabilities to get their's work right. The local goverment give it by training skill of disabilities, giving social capital, and by formating the draft of local regulation about acquirement of disabilities rights. The unity of Indonesia's Disabilities and The Unity of Deaf People of Indonesia give positive respons to the policies. But the policies which applicating by the local goverments is getting obtacles. The obtacles of application is causing by disobediently by the people and knowless of the people obout the regulation which regulating the minimum qouta of disabilities's work right.
\end{abstract}




\section{Pendahuluan}

Hak Asasi Manusia melekat pada semua manusia, termasuk bagi seorang penyandang disabilitas sekalipun. Penyandang Disabilitas menurut Undang - Undang Nomor 19 Tahun 2011 Tentang Pengesahan Convention On The Right Of Person With Disabilities (Konvensi Mengenai Hak - Hak Penyandang Disabilitas) adalah orang yang memiliki keterbatasan fisik, mental, intelektual, atau sensorik dalam jangka waktu lama yang dalam berinteraksi dengan lingkungan dan sikap masyarakatnya dapat menemui hambatan yang menyulitkan untuk berpartisipasi penuh dan efektif berdasarkan persamaan hak.

Secara konstitusional mereka (penyandang disabilitas) memiliki hak yang sama untuk dapat hidup sejahtera dengan cara mendapatkan kerja dan bekerja dengan layak. Sebagaimana tercantum dalam Pasal 28A Undang - Undang Dasar 1945 bahwa setiap orang berhak untuk hidup serta berhak mempertahankan hidup dan kehidupannya. Kemudian hak untuk mendapatkan kerja yang layak secara khusus diatur dalam Pasal 27 Ayat (2) bahwa tiap-tiap warga negara berhak atas pekerjaan dan penghidupan yang layak bagi kemanusiaan. Selain itu terdapat pula Pasal 28D Ayat (2) UUD 1945 Undang - Undang Dasar 1945 telah mengamanatkan bahwa pada dasarnya setiap orang memiliki hak untuk bekerja dan mendapat imbalan dan perlakuan yang adil serta layak dalam hubungan kerja tersebut .

Pemenuhan hak - hak tersebut tentu tidak bisa dilepaskan dari kewajiban pemerintah sebagai salah satu pemegang kekuasaan. Pemerintah memiliki kuasa untuk membuat peraturan/kebijakan sebagai representasi pemerintah untuk mewujudkan dan melindungi hak tersebut. Kewajiban pemerintah ini tertuang dalam Pasal 28I bahwa perlindungan, pemajuan, penegakan, dan pemenuhan hak asasi manusia adalah tanggung jawab negara, terutama pemerintah.

Affirmative action atau tindakan afirmatif (di Eropa disebut dengan diskriminasi positif) adalah kebijakan yang bertujuan untuk menyebarluaskan akses ke pendidikan atau pekerjaan bagi kelompok non - dominan secara sosial - politik secara sejarah (terutama untuk kaum minoritas atau perempuan). Tujuan adanya tindakan afirmatif adalah untuk mengurangi efek diskriminasi dan/atau ketidakseimbangan atas suatu kondisi terhadap golongan tertentu atau minoritas. Tindakan afirmatif turut pula dimaksudkan agar institusi - institusi publik, seperti universitas, rumah sakit, dan kepolisian agar dapat lebih mewakili populasinya/penduduknya (Subarno, 2012). Di Indonesia, afirmatif itu sendiri sebenarnya telah diatur di Undang - Undang Dasar 1945 yaitu pada Pasal 28H Ayat (2) mengatakan bahwa setiap orang berhak mendapatkan kemudahan dan perlakuan khusus untuk memperoleh kesempatan dan manfaat yang sama guna mencapai persamaan dan keadilan.

Pengertian kebijakan menurut James Anderson adalah perilaku seorang aktor (misalnya seorang pejabat, suatu kelompok, maupun suatu lembaga pemerintah) atau sejumlah aktor dalam suatu bidang kegiatan tertentu (Sunggono 1994). Pengertian lain kebijakan berasal dari Thomas R. Dye yang mengatakan bahwa kebijakan adalah apapun yang dipilih oleh pemerintah untuk dilakukan dan tidak dilakukan (Winarno 2002; Subarsono, 2012:19).

Fasilitasi, facilitation (Inggris) atau facilis (latin) artinya adalah membuat sesuatu menjadi mudah. Dalam Oxford Dictionary (2009) disebutkan facilitation is a way to render easier, to promote, to help forward; to free from difficulties and obstacles. Pengertian lain mengenai fasilitasi dikemukakan oleh Cendekia Ilham. Menurut Cendekia Ilham dalam bukunya yang berjudul "Fasilitasi Pembuatan Keputusan Partisipasif ", fasilitasi merupakan upaya dari pemimpin atau penguasa untuk mengapresiasi berbagai perspektif, pendapat, atau permasalahan yang dikemukakan oleh anggota/masyarakatnya. Tujuan dari adanya fasilitasi adalah untuk mendapatkan solusi atas masalah yang dikemukakan tersebut (Cendekia, 2010). Dalam konteks ini yang dimaksud dengan fasilitasi kerja bagi penyandang disabilitas adalah upaya atau cara untuk mempermudah penyandang disabilitas guna memperoleh kesempatan kerja yang sama dengan yang lainnya (non disabilitas). Fasilitasi kerja ini akan dilihat dari sisi kebijakan 
pemerintah, khususnya yang bersifat afirmatif bagi penyandang disabilitas.

Sebagai contoh awal mengenai upaya fasilitasi kerja pemerintah bagi penyandang disabilitas adalah melalui penetapan kuota minimal hak kerja bagi penyandang disabilitas, yaitu 1 (satu) orang penyandang disabilitas per 100 (seratus) orang pegawai. Kuota minimal tersebut tercantum dalam Pasal 14 Undang - Undang Nomor 4 Tahun 1997 Tentang Penyandang Cacat dan Pasal 28 Peraturan Pemerintah Nomor 43 Tahun 1998 Tentang Upaya Peningkatan Kesejahteraan Sosial Penyandang Cacat. Namun kuota minimal hak kerja bagi penyandang disabilitas di Provinsi Jawa Tengah tidak pernah terpenuhi. Faktanya jarang sekali peneliti dapat menemui adanya pegawai penyandang disabilitas di perusahaan - perusahaan yang berda di Provinsi Jawa Tengah. Bahkan lowongan kerja khusus bagi penyandang disabilitas pun nyaris tidak pernah ada. Sebagai contoh, bahwa di perusahaan sebesar PT. Telkom Indonesia Tbk Regional Jawa Tengah dan Daerah Istimewa Yogyakarta (DIY) yang berlokasi di Ibukota Provinsi Jawa Tengah, yaitu Kota Semarang, diketahui bahwa di perusahaan tersebut tidak ada satupun pegawai penyandang disabilitas. Kondisi yang sama terdapat pula pada salah satu perusahaan daerah di Kota Semarang yang bernama Perusahaan Daerah Air Minum (PDAM) Tirta Moedal. Bahkan PDAM Tirta Moedal menyatakan bahwa perusahannya belum pernah sekalipun membuka lowongan kerja yang dikhususkan bagi penyandang disabilitas.

Berdasarkan latar belakang tersebut, maka akan ada 3 permasalahan yang dikaji dalam penelitian ini. Pertama, akan dianalisis mengenai bentuk afirmatif kebijakan pemerintah dalam fasilitasi kerja bagi penyandang disabilitas. Kedua, akan dianalisis mengenai persepsi penyandang disabilitas terhadap afirmatif kebijakan pemerintah tersebut. Selanjutnya, akan dianalisis mengenai kendala yang dihadapi, baik oleh pemerintah maupun pengusaha/perusahaan, ketika menerapkan afirmatif kebijakan pemerintah dalam fasilitasi kerja bagi penyandang disabilitas.

\section{Metode Penelitian}

Jenis Penelitian yang digunakan dalam penelitian ini adalah Pendekatan Yuridis Sosiologis dengan pendekatan deskriptif analitif. Penelitian Yuridis Sosiologis adalah penelitian yang bertujuan untuk mengetahui bagaimana hukum itu dilaksanakan termasuk proses penegakan hukum (law enforcement) (Asikin 2006). Pendekatan deskriptif analaitif adalah jenis pendekatan yang bertujuan untuk melukiskan/menggambarkan tentang sesuatu hal di daerah tertentu dan pada saat tertentu. Hasil penelitian yang diperoleh nantinya akan dianalisis menggunakan teori - teori yang berkaitan dengan permasalahan yang diteliti (Waluyo, 2002). Sedangkan untuk mengumpulkan data, peneliti menggunakan teknik wawancara, pengamatan (observasi), dan studi kepustakaan.

\section{Hasil dan Pembahasan}

\section{a. Bentuk Afirmatif Kebijakan Pemer- intah Dalam Fasilitasi Kerja Bagi Pe- nyandang Disabilitas di Provinsi Jawa Tengah}

Berdasarkan Pasal 18 Ayat (6) Undang - Undang Dasar 1945 pemerintahan daerah memiliki wewenang untuk menetapkan peraturan daerah dan peraturan - peraturan lainnya dalam rangka melaksanakan otonomi dan tugas pembantuan. Rancangan Peraturan Daerah (Raperda) Provinsi Jawa Tengah Tentang Pemenuhan Hak Penyandang Disabilitas merupakan wujud afirmatif kebijakan pemerintah Provinsi Jawa Tengah dalam rangka memfasilitasi terpenuhinya hak - hak Penyandang Disabilitas. Mengapa disebut afirmatif kebijakan?. Karena Raperda ini secara khusus mengatur hal - hal yang hanya berkaitan dengan hak penyandang disabilitas, termasuk di dalamnya hak untuk memperoleh kerja. Raperda ini muncul untuk menguatkan hak - hak penyandang disabilitas dan sebagai wujud keberpihakan Pemerintah Provinsi Jawa Tengah terhadap penyandang disabilitas.

Dalam Raperda dijelaskan bahwa Penyandang Disabilitas adalah orang yang memiliki keterbatasan fisik, mental, intelektual, 
atau sensorik dalam jangka waktu lama atau permanen yang dalam berinteraksi dengan lingkungan dan sikap masyarakatnya dapat menemui hambatan yang menyulitkan untuk berpartisipasi penuh dan efektif berdasarkan kesamaan hak. Hak Penyandang Disabilitas adalah seperangkat hak yang melekat pada hakikat dan keberadaan penyandang disabilitas sebagai makhluk Tuhan Yang Maha Esa dan merupakan anugerah - Nya yang wajib dihormati, dijunjung tinggi dan dilindungi oleh negara, hukum, pemerintah, dan setiap orang demi kehormatan serta perlindungan harkat dan martabat manusia. Sedangkan maksud dari pemenuhan hak penyandang disabilitas adalah segala kegiatan untuk menjamin dan melindungi penyandang disabilitas dan hak - haknya agar dapat hidup, tumbuh, berkembang, dan berpartisipasi secara optimal sesuai dengan harkat dan martabat kemanusiaan serta mendapat perlindungan dari kekerasan dan diskriminasi.

Pada bab IV Pasal 14 Raperda, disebutkan bahwa hak penyandang disabilitas mencakup hak pendidikan; kesehatan; ketenagakerjaan; koperasi dan usaha mikro kecil; sosial; kebudayaan dan kepariwisataan; olahraga; politik; hukum; dan penanggulangan bencana. Sedangkan bentuk afirmatif kebijakan pemerintah dalam fasilitasi kerja bagi penyandang disabilitas secarakhusus terdapat pada terdapat Pasal 28 sampai dengan Pasal 46. Dalam pasal - pasal tersebut ada beberapa ketentuan terkait penetapan kuota minimal hak kerja bagi penyandang disabilitas. Seperti pada Pasal 34 yang mengatur mengenai kuota minimal hak kerja sebagai Calon Pegawai Negeri Sipil bagi penyandang disabilitas, yaitu sebesar 1 (satu) persen. Selain itu terdapat pula Pasal 35 Ayat (1) dan (2) yang mengatur mengenai kuota minimal hak kerja di badan hukum/perusahaan dan Badan usaha Milik Daerah, masing - masing sebesar satu pegawai penyandang disabilitas berbanding seratus pegawai non disabilitas dan satu pegawai penyandang disabilitas berbanding dua puluh lima pegawai non disabilitas.

Pemerintah daerah dan pemerintah kabupaten/kota memiliki kewajiban dan tanggung jawab untuk memenuhi hak kerja tersebut dan memfasilitasi tenaga kerja peny- andang disabilitas (Raperda Pasal 35 Ayat (3) dan Pasal 44 Ayat (1)). Selain itu, pemerintah melalui SKPD serta badan hukum, badan usaha, dan BUMD berkewajiban menjamin perlindungan tenaga kerja penyandang disabilitas sebagaimana yang diamanatkan dalam Pasal 37 Raperda. Jaminan perlindungan tenaga kerja bagi penyandang disabilitas meliputi penyediaan fasilitas kesehatan, keselamatan kerja, jaminan sosial tenaga kerja dan aksesibilitas sesuai dengan kebutuhan tenaga kerja penyandang disabilitas.

Selain melalui Raperda Tentang Pemenuhan Hak Penyandang Disabilitas, bentuk afirmatif kebijakan lain yang dilakukan oleh Pemerintah Provinsi Jawa Tengah dalam rangka fasilitasi kerja bagi penyandang disabilitas adalah dengan memberikan pelatihan keterampilan dan bantuan sosial. Pelatihan keterampilan dan bantuan sosial ini menjadi tanggung jawab dan tugas Dinas Sosial Provinsi Jawa Tengah serta Balai Pelatihan Transmigrasi dan Penyandang Cacat (Balatrans Penca) Provinsi Jawa Tengah. Dinas Sosial Provinsi Jawa Tengah melalui Seksi Pengembangan Pelayanan Kesejahteraan Sosial mempunyai tugas untuk memberikan pelatihan bagi penyandang disabilitas. Tujuan pemberian pelatihan keterampilan adalah untuk memberikan bekal (kemampuan) kepada penyandang disabilitas agar penyandang disabilitas tersebut dapat melakukan fungsi sosial sebagaimana manusia lainnya (Sarwati, Kepala Seksi Pengembangan Pelayanan Kesejahteraan Sosial) Pelatihan keterampilan diberikan kepada penyandang disabilitas fisik (tangan atau kaki) atau tuna daksa, dimana bentuk pelatihan yang telah diberikan oleh Dinas Sosial adalah pelatihan menjahit.

Berdasarkan Laporan Tahunan Kegiatan Pendidikan Kemasyarakatan Pelatihan Keterampilan Bagi Penyandang Disabilitas, diketahui bahwa pada Tahun 2013 lalu, Dinas Sosial Provinsi Jawa Tengah telah memberikan pelatihan keterampilan menjahit kepada para penyandang disabilitas (khusus tuna daksa) di tiga kabupaten/kota dengan jumlah peserta secara keseluruhan sebanyak 90 (sembilan puluh) orang. Berikut rekap jumlah peserta pelatihan: 
Tabel 1. Rekap Jumlah Peserta Pelatihan Keterampilan Menjahit Bagi Penyandang Disabilitas

\begin{tabular}{lccc}
\hline Kabupaten/ & Jumlah & \multicolumn{2}{c}{ Jenis Kelamin } \\
\cline { 3 - 4 } \multicolumn{1}{c}{ Kota } & Peserta & L & P \\
\hline Temanggung & 30 & 14 & 16 \\
Wonogiri & 30 & 21 & 9 \\
Sukoharjo & 30 & 15 & 15 \\
\hline Jumlah & $\mathbf{9 0}$ & $\mathbf{5 0}$ & $\mathbf{4 0}$ \\
\hline
\end{tabular}

Sumber: Dinas Sosial Provinsi Jawa Tengah

Selain Dinas Sosial Provinsi Jawa Tengah, pelatihan bagi penyandang disabilitas sebagai wujud afirmatif kebijakan pemerintah dalam fasilitasi kerja bagi penyandang disabilitas di Provinsi Jawa Tengah turut pula diberikan oleh Balatrans Penca. Balatrans Penca adalah unit pelaksana kerja bidang transmigrasi dan ketenagakerjaan yang berada di bawah Dinas Tenaga Kerja, Transmigrasi dan Kependudukan Provinsi Jawa Tengah. Pelatihan yang diberikan oleh Balataran Penca didasarkan pada "training need" atau kebutuhan pelatihan di wilayah kabupaten/ kota peserta pelatihan. Peserta pelatihan yang dilatih adalah penyandang disabilitas fisik dengan derajat kecacatan tunggal, seperti penyandang disabilitas kaki.

Berikut ini adalah jenis pelatihan yang sudah dilaksanakan oleh Balatrans Penca pertahun 2013 dalam rangka peningkatan kualitas dan produktivitas tenaga kerja penyandang disabilitas.

\section{Pelatihan Sablon}

Peserta pelatihan berjumlah 20 (dua puluh) orang yang berasal dari Kabupaten Sragen, Batang, Demak, dan Temanggung.

\section{Pelatihan Elektronika Dasar}

Peserta pelatihan berjumlah 20 (dua puluh) orang yang berasal dari Kabupaten Temanggung, Rembang, Magelang, Kendal, Banjarnegara, Boyolali, Demak, Semarang, dan Kota Semarang.

\section{Pelatihan Komputer}

Peserta pelatihan berjumlah 20 (dua puluh) orang yang berasal dari Kabupaten
Wonogiri, Wonosobo, Kudus, dan Kota Semarang.

Berdasarkan keterangan yang diberikan oleh Sutiyono, Instruktur Kegiatan Pelatihan Komputer dari Balatrans Penca, disebutkan bahwa materi pelatihan komputer meliputi 3 (tiga) hal, yaitu:

a) Microsoft Word;

b) Microsoft Excel; dan

c) Microsoft Power Point.

(Berdasarkan wawancara tertanggal 11 April 2014, Pukul 14:15 WIB)

\section{Pelatihan Anyaman}

Peserta pelatihan berjumlah 15 (lima belas) orang yang berasal dari Kabupaten Pemalang, Kudus, Klaten, dan Banjarnegara. Adapun peserta pelatihan sebagai berikut:

Sementara afirmatif kebijakan pemerintah melalui pemberian bantuan sosial bagi penyandang disabilitas merupakan tanggung jawab dan tugas Seksi Pelayanan dan Rehabilitasi Sosial Penyandang Disabilitas, Dinas Sosial Provinsi Jawa Tengah. Bantuan Sosial merupakan bantuan modal usaha yang diberikan oleh Dinas Sosial untuk perseorangan penyandang disabilitas. Besar bantuan yang diberikan adalah Rp 1.150.000 (satu juta seratus lima puluh ribu rupiah) untuk 1 (satu) orang penyandang disabilitas. Namun bantuan tidak diberikan dalam bentuk uang, melainkan barang yang siap untuk digunakan/dijual oleh penyandang disabilitas. Pemberian bantuan sosial ini diberikan kepada penyandang disabilitas yang memiliki kriteria sebagai berikut;

1. Tidak mampu/miskin;

2. Memiliki embrio usaha.

Adapun tahapan pemberian bantuan sosial meliputi;

1. seleksi: pada tahap ini Dinas Sosial Provinsi Jawa Tengah akan menyeleksi pendaftar calon penerima bantuan sosial. Pendaftar yang dinyatakan lolos adalah pendaftar yang memenuhi kriteria, sebagaimana yang telah disebutkan diatas;

2. bimbingan pemantapan: pada tahap ini pendaftar penyandang disabilitas yang telah dinyatakan lolos seleksi, dipersilahkan membawa proposal 
yang berisi kebutuhan penyandang disabilitas untuk melaksanakan usaha, sebagaimana embrio usaha yang bersangkutan.

3. penyerahan bantuan: pada tahap ini bantuan diserahkan, besar bantuan sebesar 1.150.000 per orang, namun bantuan diserahkan dalam bentuk barang;

4. pembinaan perorangan: pada tahap ini, pihak dinas sosial melalui unit pelaksanan terkait tingkat kabupaten/ kota melakukan pembinaan bagi penyandang disabilitas dari rumah ke rumah. Tujuannya adalah untuk memastikan bahwa bentuk bantuan sosial yang diberikan telah dimanfaatkan sebagaimana mestinya. Pembinaan ini juga dimaksudkan sebagai bentuk pengawasan dari Dinas Sosial.

\section{b. Persepsi Kelompok Penyandang Dis- abilitas Terhadap Afirmatif Kebijakan Pemerintah Dalam Fasilitasi Kerja Bagi Penyandang Disabilitas di Provinsi Jawa Tengah}

Pada bagian ini, peneliti akan menguraikan pendapat dari perwakilan kelompok penyandang disabilitas terkait persepsi kelompok penyandang disabilitas terhadap afirmatif kebijakan pemerintah dalam fasilitasi kerja bagi penyandang disabilitas di Provinsi Jawa Tengah.

Ir. Ronny Hudi Prakoso, selaku Ketua Persatuan Penyandang Cacat Indonesia untuk daerah Provinsi Jawa Tengah, berpendapat bahwa saat ini telah ada upaya dari pemerintah dalam rangka fasilitasi kerja bagi penyandang disabilitas. Salah satu bentuk upayanya adalah melalui pelatihan. Adapun contoh pelatihan yang pernah diberikan adalah pelatihan menjahit, menganyam, sablon, dan komputer. Namun beliau merasa bahwa jenis pelatihan yang saat ini dilakukan oleh Pemerintah Provinsi Jawa Tengah sudah tidak lagi sesuai dengan perkembangan jaman, bahkan tidak mampu lagi memenuhi kebutuhan hidup penyandang disabilitas. Sebagai contoh, pemberian pelatihan ketarampilan menjahit. Beliau berpendapat bahwa saat ini antara menjahit dengan beli baju di toko, biayanya justru lebih murah beli di toko. Padahal untuk seorang penjahit penyandang disabilitas, tentu menghasilkan 1 (satu) buah baju akan menghabiskan waktu yang lebih lama dibanding penjahit lain yang normal. Sehingga dilihat dari proses ini saja, sudah sangat wajar apabila harga baju hasil jahitan mereka (penyandang disabilitas) menjadi sedikit lebih tinggi (mahal). Namun sayangnya masyarakat tidak memerdulikan hal tersebut. Beliau menyatakan bahwa masalah ini sudah sering diungkapkan oleh kelompok penyandang disabilitas, hanya saja sampai saat ini tidak ada tanggapan atau respon dari pemerintah. Buktinya pemerintah tetap saja melakukan pelatihan dengan jenis pelatihan yang demikian.

Sedangkan menanggapi hak penyandang disabilitas mengenai kuota minimal hak kerja sebagaimana Pasal 14 UU 4/1997, Ir. Ronny Hudi Prakoso berpendapat bahwa kuota tersebut tidak pernah terpenuhi, baik untuk di perusahaan swasta maupun daerah (BUMD). Penyandang disabilitas masih merasa kesulitan untuk memperoleh kerja. Ir. Ronny Hudi Prakoso, menyebutkan bahwa kesulitan tersebut dipengaruhi oleh 3 (tiga) faktor utama yaitu:

a. faktor pendidikan;

b. faktor aksesibilitas; dan

c. faktor kesamaan kesempatan.

Faktor pendidikan adalah penyebab utama penyandang disabilitas sulit mendapatkan kerja. Hal ini dikarenakan tingkat pendidikan penyandang disabilitas yang rata - rata rendah. Pendapat beliau mengenai rendahnya tingkat pendidikan penyandang disabilitas rupanya sesuai dengan data lain yang peneliti peroleh dari Balatrans Penca. Bila melihat dari data peserta pelatihan Balatrans Penca (tabel 2, 3, dan 4) diketahui bahwa rata - rata pendidikan penyandang disabilitas hanyalah tamatan Sekolah Dasar (SD). Penyandang Disabilitas tamatan SD mencapai 25 orang dari jumlah peserta pelatihan sebanyak 60 orang. Sedangkan tamatan SMP sebanyak 22 orang, SMA 10 orang, dan perguruan tinggi hanya 3 orang. Adapun data mengenai tingkat pendidikan tersebut secara ringkas dapat dilihat pada Tabel 2.

Kehadiran Raperda Tentang Pemenu- 
Tabel 2. Tingkat Pendidikan Peserta Pelatihan Penyandang Disabilitas

\begin{tabular}{|c|c|c|c|c|c|}
\hline \multirow{2}{*}{ Jenis Pelatihan } & \multirow{2}{*}{$\begin{array}{l}\text { Jumlah } \\
\text { Peserta }\end{array}$} & \multicolumn{4}{|c|}{ Pendidikan Terakhir } \\
\hline & & SD & SMP & SMA & Perguruan Tinggi \\
\hline Sablon & 20 & 9 & 8 & 2 & 1 \\
\hline Elektonika Dasar & 20 & 12 & 5 & 2 & 1 \\
\hline Komputer & 20 & 4 & 9 & 6 & 1 \\
\hline Jumlah & 60 & 25 & 22 & 10 & 3 \\
\hline
\end{tabular}

Sumber: Balatrans Penca

han Hak Penyadang Disabilitas menjadi sebuah harapan baru. Ir. Ronny Hudi Prakoso berharap bahwa adanya pengaturan mengenai kuota minimal hak kerja bagi penyandang disabilitas yang lebih variatif mampu memberikan peluang kerja yang lebih besar bagi penyandang disabilitas, baik di perusahaan maupun instansi pemerintahan. Terlebih dalam Raperda tersebut diatur mengenai adanya perluasan kesempatan kerja bagi penyandang disabilitas, yaitu melalui usaha mandiri produktif. Dengan adanya kesempatan usaha mandiri, penyandang disabilitas memiliki kesempatan kerja jauh lebih besar dan dapat berpenghasilan lebih banyak. Namun usaha mandiri produktif ini harus dibarengi dengan kebijakan - kebijakan lain dari pemerintah yang sifatnya afirmatif bagi penyandang disabilitas. Misal dengan diterbitkannya kebijakan yang mengatur kemudahan peminjaman modal bagi penyandang disabiltas dengan suku bunga yang murah.

Respon berbeda ditunjukan oleh Setyo Martono, anggota Gerakan Untuk Kesejahteraan Tuna Rungu Indonesia (Gerkatin) Kota Semarang. Sebagai perwakilan dari penyandang disabilitas tuna rungu, Setyo Martono, mengklaim bahwa mayoritas penyandang disabilitas tuna rungu tidak mengetahui adanya afrimatif kebijakan pemerintah tentang penetapan kuota minimal hak kerja bagi penyandang disabilitas, baik yang tercantum dalam Undang - Undang Nomor 4 Tahun 1997 Tentang Penyandang Cacat maupun Peraturan Pemerintah Nomor 43 Tahun 1998 Tentang Upaya Peningkatan Kesejahteraan Sosial Penyandang Cacat. Menurut Setyo Martono, meskipun penetapan kuota minimal hak kerja bagi penyandang disabilitas telah diatur dalam peraturan perundang
- undangan, namun pada kenyataannya perusahaan baik swasta maupun daerah, tetap tidak bersedia menerima tenaga kerja penyandang disabilitas.

Setyo Martono menyatakan bahwa afirmatif kebijakan pemerintah yang ada saat ini dinilai masih belum mampu memenuhi kebutuhan penyandang disabilitas, khususnya dalam hal kebutuhan untuk mendapatkan kerja. Nyatanya banyak penyandang disabilitas yang masih menganggur/tidak bekerja. Namun beliau tidak memungkiri bahwa sejauh ini pernah ada bantuan dari pemerintah bagi penyandang disabilitas. Bantuan yang dimaksud merupakan bantuan modal untuk membuka usaha/berwirausaha. Hanya saja, biasanya pemerintah memberikan bantuan modal bagi penyandang disabilitas yang sudah memiliki profesi/keahlian kerja. Misalnya penyandang disabilitas yang memiliki keterampilan menjahit, maka diberikan bantuan berupa mesin jahit/obras. Sementara bagi penyandnag disabilitas lainnya, yang belum memiliki keahlian, kurang diperhatikan kebutuhannya.

Setyo Martono berharap ke depannya, pemerintah dapat lebih memperhatikan kebutuhan penyandang disabilitas, khususnya dalam hal pekerjaan. Selain itu, pola perekrutan tenaga kerja juga harus diubah, dimana sebaiknya tidak lagi menggunakan surat lamaran kerja. Hal ini dikarenakan pengalaman kerja penyandang disabilitas "diatas kertas" tentu jauh dibawah orang normal pada umumnya, sehingga bila melihat kemampuan kerja penyandang disabilitas dari apa yang tertuang di kertas tersebut, maka peluang kerja bagi penyandang disabilitas pun akan semakin kecil. Untuk itu, strategi terbaik adalah pemerintah harus lihat langsung ke la- 
pangan agar dapat mengetahui secara detail potensi kerja atau keterampilan yang dimiliki oleh masing - masing penyandang disabilitas.

\section{c. Kendala yang Dihadapi Dalam Melaksanakan Afirmatif Kebijakan Pemerintah Mengenai Fasilitasi Kerja bagi Penyandang Disabilitas di Provin- si Jawa Tengah}

Setiap kebijakan pasti menghadapi kendala dalam hal penerapannya. Pada bagian ini, peneliti akan mendeskripsikan kendala - kendala apa saja yang dihadapi, baik pemerintah maupun pihak perusahaan terkait pelaksanaan afirmatif kebijakan pemerintah dalam fasilitasi kerja bagi penyandang disabilitas di Provinsi Jawa Tengah. Afirmatif kebijakan pemerintah yang dimaksud peneliti pada bagian ini adalah segala afirmatif kebijakan Pemerintah tentang fasilitasi kerja bagi penyandang disabilitas, terkecuali Rancangan Peraturan Daerah Provinsi Jawa Tengah Tentang Pemenuhan Hak Penyandang Disabilitas.

Berdasarkan penelitian yang telah dilakukan, pemerintah yang dalam hal ini dimaksudkan pada eksekutif, memiliki kendala dalam hal melaksanakan tanggung jawabnya terkait fasilitasi kerja bagi penyandang disabilitas. Kendala itu muncul baik dalam hal upaya pemerintah untuk memenuhi kuota minimal hak kerja maupun mengenai kebijakan pemerintah dalam hal memberikan pelatihan dan dana bantuan sosial bagi penyandang disabilitas.

Sebagaimana dikemukakan oleh Harni Sarwati, SH, MH, Kepala Seksi Pengembangan Pelayanan Kesejahteraan Sosial, Dinas Sosial Provinsi Jawa Tengah, bahwa selama ini pemerintah Provinsi Jawa Tengah telah berupaya untuk memenuhi hak - hak dasar penyandang disabilitas, termasuk hak untuk memperoleh kerja. Namun segala upaya yang telah dilakukan memang dirasa belum optimal. Beliau menjelaskan bahwa tidak terpenuhinya kuota minimal hak kerja bagi penyandang disabilitas diakibatkan ketidakpatuhan pihak - pihak terkait terhadap Undang - Undang Nomor 4 Tahun 1997 Tentang Penyandang Cacat dan Peraturan Pemerintah Nomor 43 Tahun 1998 Tentang Upaya
Peingkatan Kesejahteraan Sosial Penyandang Cacat. Pihak - pihak yang dimaksud adalah intansi atau lembaga pemerintah dan perusahaan baik swasta maupun daerah/BUMD.

Berbeda dengan apa yang dikemukakan oleh Harni Sarwati, SH, MH, Dra. Nanik Setyawati selaku Seksi Pelayanan dan Rehabilitasi Sosial Penyandang Disabilitas, Dinas Sosial Provinsi Jawa Tengah, menitikberatkan kendala pada penyandang disabilitas itu sendiri. Menurutnya, belum optimalnya pemberdayaan penyandang disabilitas sebagai tenaga kerja adalah dikarenakan banyaknya penyandang disabilitas yang tidak memiliki embrio usaha. Hal ini berakibat pada sulitnya pemerintah untuk menentukan pelatihan kerja seperti apa, yang tepat bagi penyandang disabilitas tersebut. Kendala juga dihadapi ketika pemerintah memberikan bantuan sosial sebagai modal usaha. Banyak penyandang disabilitas yang tidak sabar dalam menjalankan usahanya dikarenakan jumlah pendapatan/penghasilan yang sedikit.

Darwiji, Kepala Seksi Pelatihan, Balai Pelatihan Transmigrasi dan Penyandang Cacat (Balatrans Penca) berpendapat bahwa Balatrans Penca telah melaksanakan kewajibannya dalam hal memenuhi hak kerja bagi penyandang disabilitas. Pemenuhan hak kerja itu diberikan melalui pelatihan keterampilan yang diselenggarakan oleh Balatrans Penca. Sementara terkait kuota minimal hak kerja penyandang disabilitas yang selama ini belum terpenuhi, Darwiji berpendapat bahwa permasalahannya terletak pada perusahaan. Mayoritas perusahaan menolak untuk menerima tenaga kerja penyandang disabilitas dengan alasan yang klasik, yaitu anggapan tentang ketidakmampuan penyandang disabilitas dalam hal meningkatkan produktivitas perusahaan bila dibandingkan dengan tenaga kerja yang non penyandang disabilitas.

Selain pemerintah, pihak perusahaan juga mengalami kendala dalam rangka melaksanakan afirmatif kebijakan pemerintah tersebut. Sebagaimana penelitian yang dilakukan peneliti di Perusahaan Daerah Air Minum (PDAM) Tirta Moedal, Kota Semarang. Kepala Sub Bagian Administrasi Kepegawaian, Hendrawan Djatmiko, S.H., menjelaskan bahwa kendala yang mungkin dihadapi pe- 
rusahaan, apabila nantinya mempekerjakan tenaga kerja/pegawai penyandang disabilitas adalah terkait sarana dan prasarana. Beliau berpendapat bahwa sarana dan prasarana ini merupakan hal yang penting karena akan menjadi faktor pendukung kerja bagi pegawai penyandang disabilitas yang bersangkutan.

Lebih lanjut dijelaskan bahwa PDAM Tirta Moedal kemungkinan sulit untuk menerima pegawai penyandang disabilitas, karena pada dasarnya perusahaan tersebut lebih membutuhkan pegawai yang notabenenya memiliki kekuatan fisik yang baik. Hal ini dalam rangka untuk mencapai produktivitas terbaik sebagaimana yang diharapkan perusahaan. Terlebih untuk pegawai yang nantinya akan di tempatkan di lapangan/teknis, misal di bagian produksi, kriteria pegawai dengan fisik yang kuat akan menjadi pertimbangan utama. Namun kedepannya, tidak menutup kemungkinan bagi PDAM Tirta Moedal untuk menerima pegawai dari penyandang disabilitas. Sementara untuk penempatannya, paling mungkin pegawai penyandang disabilitas tersebut ditempatkan di bagian yang sifatnya administratif, misal di direktorat umum (keuangan atau kepegawaian), call center, atau di loket pembayaran yang pada prinsipnya tidak terlalu membutuhkan gerak fisik yang banyak. Adapun jenis penyandang disabilitas yang memungkinkan untuk dipekerjakan di PDAM Tirta Moedal adalah penyandang disabilitas fisik dengan derajat disabilitas yang rendah, misal penyandang disabilitas yang tidak punya kaki atau tidak bisa berjalan, sehingga tangannya masih dapat digunakan untuk bekerja, misal untuk mengangkat telepon atau mengoperasikan komputer.

\section{Simpulan}

Berdasarkan hasil penelitian dan pembahasan diperoleh simpulan sebagai berikut: Pertama, bentuk afirmatif kebijakan pemerintah dalam fasilitasi kerja bagi penyandang disabilitas di Provinsi Jawa Tengah diwujudkan melalui Rancangan Peraturan Daerah (Raperda) Provinsi Jawa Tengah Tentang Pemenuhan Hak Penyandang Disabilitas serta pemberian pelatihan keterampilan dan ban- tuan sosial; Kedua, Persatuan Penyandang Cacat Indonesia menilai bahwa pelatihan yang diberikan pemerintah dirasa sudah tidak sesuai lagi dengan perkembangan jaman dan kebutuhan hidup penyandang disabilitas. Hal serupa turut disuarakan oleh Gerkatin. Sedangkan tentang kehadiran Raperda, baik Persatuan Penyandang Cacat Indonesia maupun Gerkatin memberikan respon positif; Ketiga, faktor penyebab belum dapat terlaksananya afirmatif kebijakan pemerintah yang ada saat ini dikarenakan ketidakpatuhan pihak - pihak terkait (pemerintah maupun pihak perusahaan), serta ketidaktahuan pihak perusahaan mengenai adanya aturan tentang kuota minimal hak kerja bagi penyandang disabilitas.

\section{Daftar Pustaka}

Asikin, A. Zainal. 2006. Pengantar Metode Penelitian Hukum. Jakarta: PT. Raja Grafindo Persada.

Cendekia, Ilham. 2010. Fasilitasi Pembuatan Keputusan Partisipasif. Jakarta: Pusat Telaah dan Informasi Regional.

Dinas Sosial Provinsi Jawa Tengah. 2013. Laporan Tahunan Kegiatan Pendidikan Kemasyarakatan: Pelatihan Keterampilan Bagi Penyandang Disabilitas Tahun 2013. Semarang.

Oxford Dictionary, Fourth Edition. 2009. New York: Oxford University Press.

Subarsono, AG. 2012. Analisis Kebijakan Publik: Konsep, Teori, dan Aplikasi. Yogyakarta: Pustaka Pelajar.

Waluyo, Bambang. 2002. Penelitian Hukum Dalam Praktek. Jakarta: Sinar Grafika.

Winarno, Budi. 2002. Teori dan Proses Kebijakan Publik. Yogyakarta: MediaPressindo.

\section{Peraturan Perundang - Undangan}

Undang - Undang Dasar Republik Indonesia Tahun 1945

Undang - Undang Nomor 4 Tahun 1997 Tentang Penyandang Cacat

Undang - Undang Nomor 19 Tahun 2011 Tentang Pengesahan Convention On The Right Of Person With Disabilities (Konvensi Mengenai Hak - Hak Penyandang Disabilitas)

Peraturan Pemerintah Nomor 43 Tahun 1998 Tentang Upaya Peningkatan Kesejahteraan Sosial Penyandang Cacat 